\title{
Influence of 2008 Wenchuan earthquake on earthquake occurrence trend of active faults in Sichuan-Yunnan region*
}

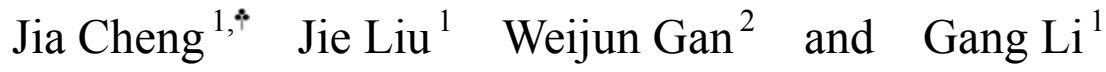 \\ ${ }^{1}$ China Earthquake Networks Center, Beijing 100045, China \\ ${ }^{2}$ State Key Laboratory of Earthquake Dynamics, Institute of Geology, \\ China Earthquake Administration, Beijing 100029, China
}

\begin{abstract}
The Wenchuan earthquake coseismic deformation field is inferred from the coseismic dislocation data based on a 3-D geometric model of the active faults in Sichuan-Yunnan region. Then the potential dislocation displacement is inverted from the deformation field in the 3-D geometric model. While the faults' slip velocities are inverted from GPS and leveling data, which can be used as the long-term slip vector. After the potential dislocation displacements are projected to long-term slip direction, we have got the influence of Wenchuan earthquake on active faults in Sichuan-Yunnan region. The results show that the northwestern segment of Longmenshan fault, the southern segments of Xianshuihe fault, Anninghe fault, Zemuhe fault, northern and southern segments of Daliangshan fault, Mabian fault got earthquake risks advanced of 305, 19, 12, 9.1 and 18, 51 years respectively in the eastern part of Sichuan and Yunnan. The Lijiang-Xiaojinhe fault, Nujiang fault, Longling-Lancang fault, Nantinghe fault and Zhongdian fault also got earthquake risks advanced in the western part of Sichuan-Yunnan region. Whereas the northwestern segment of Xianshuihe fault and Xiaojiang fault got earthquake risks reduced after the Wenchuan earthquake.
\end{abstract}

Key words: Wenchuan earthquake; coseismic deformation; active fault; earthquake occurrence trend; SichuanYunnan region

CLC number: P315.72 5 Document code: A

\section{Introduction}

The Wenchuan $M_{\mathrm{S}} 8.0$ earthquake, which caused more than 80000 death, occurred on the Longmenshan fault in the North-South seismic belt, China, on May 12, 2008. Because of the specialty of the regional tectonic environment, especially the central Tibetan plateau's eastward extrusion and following obstruction from Sichuan basin, the direction of crustal deformation changes obviously accompanied with stress and strain. These changes have nurtured active faults, complicated structures and frequent major earthquakes in Sichuan-Yunnan region (Clark et al, 2005; Burchfiel et al, 2008). The Wenchuan $M_{\mathrm{S}} 8.0$ earthquake, followed by the modification of regional crustal deformation field and switch of

\footnotetext{
* Received 5 December 2008; accepted in revised form 18 June 2009; published 10 October 2009

^ Corresponding author. e-mail: chengjiajc@gmail.com
}

tectonic blocks movement direction, caused the regional crustal deformation changed (Working Group of State Key Scientific Project and Crustal Movement Observation Network of China, 2008), which will finally have some influence on the earthquake occurrence trend of other faults. As a result, it is important to study this influence. Nowadays, the common method to obtain this influence is from the Coulomb stress changes (Wan et al, 2007; Wang et al, 2008a; Parsons, 2002). The influence on surrounding faults from the Wenchuan $M_{\mathrm{S}} 8.0$ earthquake is given by the Coulomb stress changes of Wenchuan earthquake, too (Parsons et al, 2008; Toda et al, 2008; Wan et al, 2009). However, most of these studies only gave the results that earthquake occurrence trend advanced or reduced of the faults but without the degree of this influence relative to background values. Trying to improve this method, Parsons (2002) used finite element method (FEM) to study the Coulomb stress change of 1906 San Francisco earthquake. 
In order to obtain Wenchuan earthquake's influence on earthquake occurrence trend of active faults in Sichuan-Yunnan region, we firstly calculate the coseismic deformation field of this region using the Wenchuan earthquake coseismic rupture data with 3-D half-space elastic dislocation model (Okada, 1985, 1992), then use the half-space elastic dislocation model to invert the potential dislocation displacements constrained by the coseismic deformation field in the geometric model of regional faults, finally compare the displacements with the background values of fault slip rate inverted from GPS and leveling data (Cheng, 2008). Final results will be given in the form of how many years the earthquake occurrence trend advanced or reduced.

\section{3-D half-space elastic coseismic and interseismic dislocation model}

The 3-D half-space elastic dislocation model is adopted in our coseismic and interseismic simulation. This model is based on Okada's elastic dislocation theory (Okada, 1985, 1992). Okada (1992) presented a complete set of closed analytical expressions for the internal and surface displacements, strains and tilts by shear and tensile faults in a half-space. Once the fault dislocates, the surface displacement is decided by the following parameters: displacement of dislocation surface, distance from the surface point to source, the size of source plane, dip angle and locking depth of the source plane, and medium parameters of the elastic body ( $\lambda, \mu$, respectively). If there are more than one dislocation rectangle sources in the elastic body, the displacement can be thought as the summation of the displacement induced by each source.

We will use the 3-D half-space elastic dislocation model to calculate the coseismic deformation field and to invert the influence on the earthquake occurrence trends of other fault segments from the deformation field. In the model, the crust is taken as an elastic body, and the fault is located under some depth called as locking depth. This locking depth divides the crust into two layers, seismogenic layer and dislocation layer. In the interseismic dislocation model, the fault can be explained as continuous movement of dislocation layer with seismogenic layer locking. In the coseismic dislocation model (Figure 1), the seismogenic layer ruptures abruptly while dislocation layer is locking relatively (Prescott et al, 1986; Savage et al, 1999).

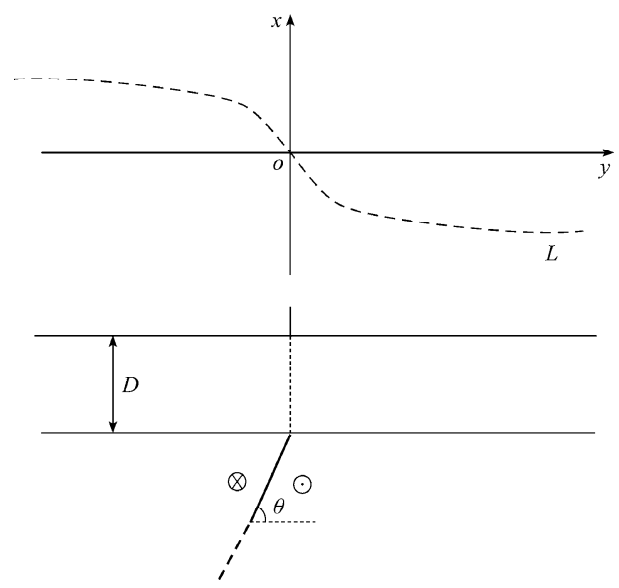

Figure 1 Sketch of 3-D half-space elastic dislocation model. $D$ is the locking depth, $\theta$ is the dip-angle of the fault, and $L$ is coseismic deformation field induced by the fault.

This paper firstly calculates the coseismic deformation field using the coseismic rupture data (Ji and Hayes, 2008), then inverts the potential dislocation displacements of regional faults in the coseismic deformation field. Because the present slip vectors of these faults have been given in former work using both the same dislocation method and geometric fault model inferred from GPS and leveling data (Cheng, 2008), we project the potential dislocation displacements to the present slip direction of these faults, and get the results that how many years the earthquake occurrence trends have been influenced after the Wenchuan earthquake.

\section{Geometric model and present-day long-term slip velocities of the faults in Sichuan-Yunnan region}

Because of the specialty of the regional tectonic environment, large number of faults and tectonic structures have been nurtured in Sichuan-Yunnan region, so it is necessary to simplify these faults. We have simplified the faults in this region referring to plenty of results from geological observations and GPS studies, and obtained the 3-D geometric model of the active faults (Figure 2) (Cheng, 2008). The principles of fault simplification are as follows.

1) The faults only with large scale and obvious activity are selected, considering the various faults with different scale and different activity distributed in the region.

2) As to each main active fault, it can be composed 
of a series of linked fault segments with the same dip direction, dip angle and locking depth.

3) We divide the fault into different segments at the points where surface track jumps or where slip characteristic changes abruptly. The linked fault segments can also have different fault parameters, and be constrained with the same fault parameters if necessary.

4) As to the fault systems with two or more than two parallel faults, we only use one to substitute these faults, and movement parameters of this fault can reflect that of the whole.

5) According to the rupture characteristic of the Wenchuan $M_{\mathrm{S}} 8.0$ earthquake, the Longmenshan fault is refined into five segments (Zhou et al, 2000), i.e., SW segment, middle II segment, middle I segment, NE seg- ment and Qingchuan fault; whereas the Xianshuihe fault, where have occurred at least eight $M \geq 7$ earthquakes since $\mathrm{AD} 1873$, is also refined into six segments (Wen et al, 1989; Xu et al, 2003) (Figure 3).

In addition, we tried to make the faults in the model to be close, so the end-point effect of the inversion can be decreased and also the whole movement of active block enclosed by faults has been clearly reflected.

After the above processions, we have got the 3-D geometric model of the active faults in the SichuanYunnan region; the fault segments and their parameters are listed in Table 1. The parameters consist of dip, dip angle and locking depth. The locking depths are the depths where small earthquake are lacked from small earthquakes relocation (Zhu et al, 2005). And also the

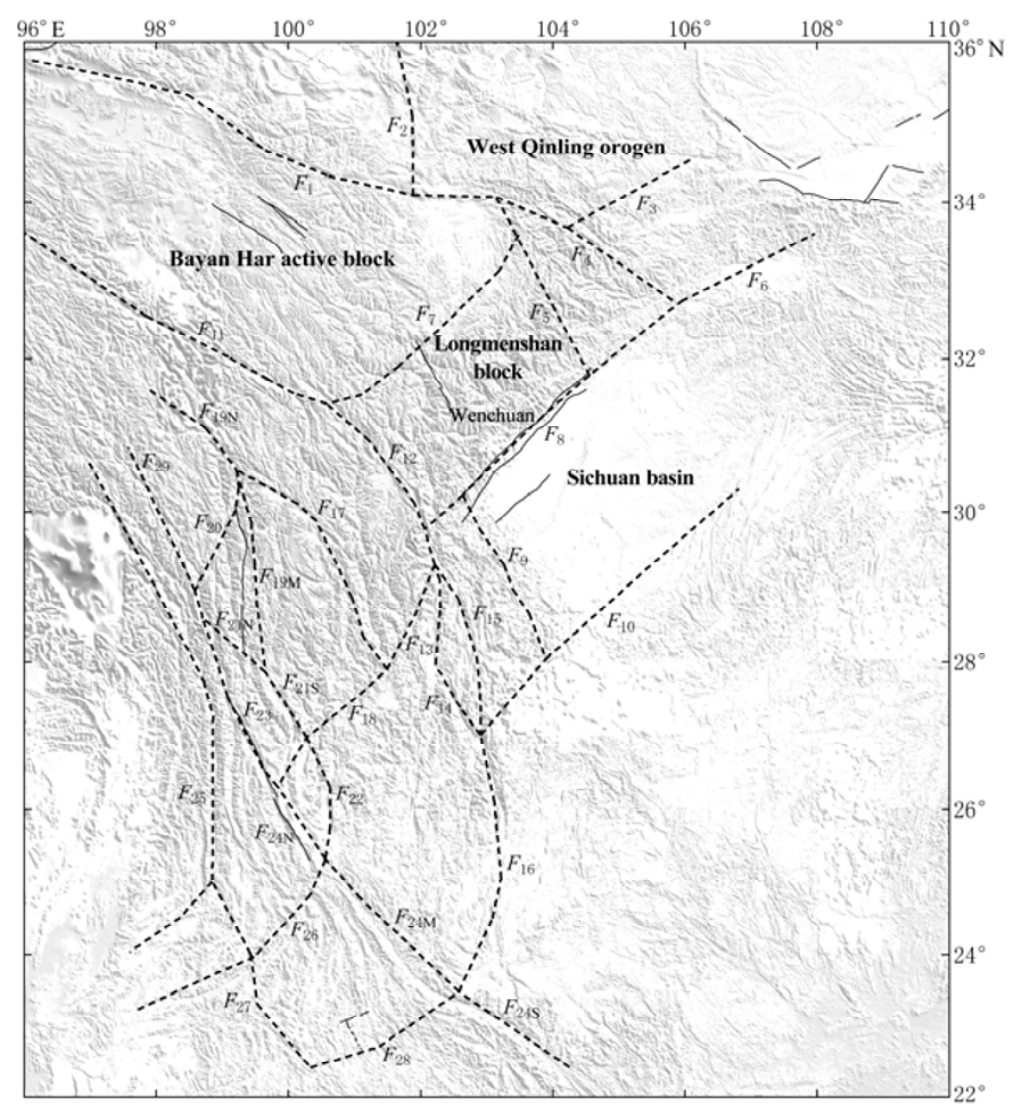

Figure 2 Geometrical active fault model of Sichuan-Yunnan region modified from Active Tectonics Map of China (Deng, 2007). $F_{1}$. Eastern Kunlun fault; $F_{2}$. Riyueshan fault; $F_{3}$. Lixian-Luojiapu fault; $F_{4}$. South boundary fault of west Qinling orogen; $F_{5}$. Minjiang fault; $F_{6}$. Qingchuan fault; $F_{7}$. Longriba fault; $F_{8}$. Longmenshan fault; $F_{9}$. Mabian fault; $F_{10}$. Huayingshan fault; $F_{11}$. Garze-Yushu fault; $F_{12}$. Xianshuihe fault; $F_{13}$. Anninghe fault; $F_{14}$. Zemuhe fault; $F_{15}$. Daliangshan fault; $F_{16}$. Xiaojiang fault; $F_{17}$. Litang fault; $F_{18}$. Lijiang-Xiaojinhe fault; $F_{19 \mathrm{~N}}$. Northern segment of Jinshajiang fault; $F_{19 \mathrm{M}}$. Middle segment of Jinshajiang fault; $F_{20}$. Batang fault; $F_{21 \mathrm{~N}}$. Northern segment of Zhongdian fault; $F_{21 \mathrm{~S}}$. Southern segment of Zhongdian fault; $F_{22}$. Chenghai fault; $F_{23}$. Weixi-Qiaohou fault; $F_{24 \mathrm{~N}}$. Northern segment of Honghe fault; $F_{24 \mathrm{M}}$. Middle segment of Honghe fault; $F_{245}$. Southern segment of Honghe fault; $F_{25}$. Nujiang fault; $F_{26}$. Nantinghe fault; $F_{27}$. Longling-Lancangjiang fault; $F_{28}$. Jinghong fault; $F_{29}$. Northern segment of Lancangjiang fault. 


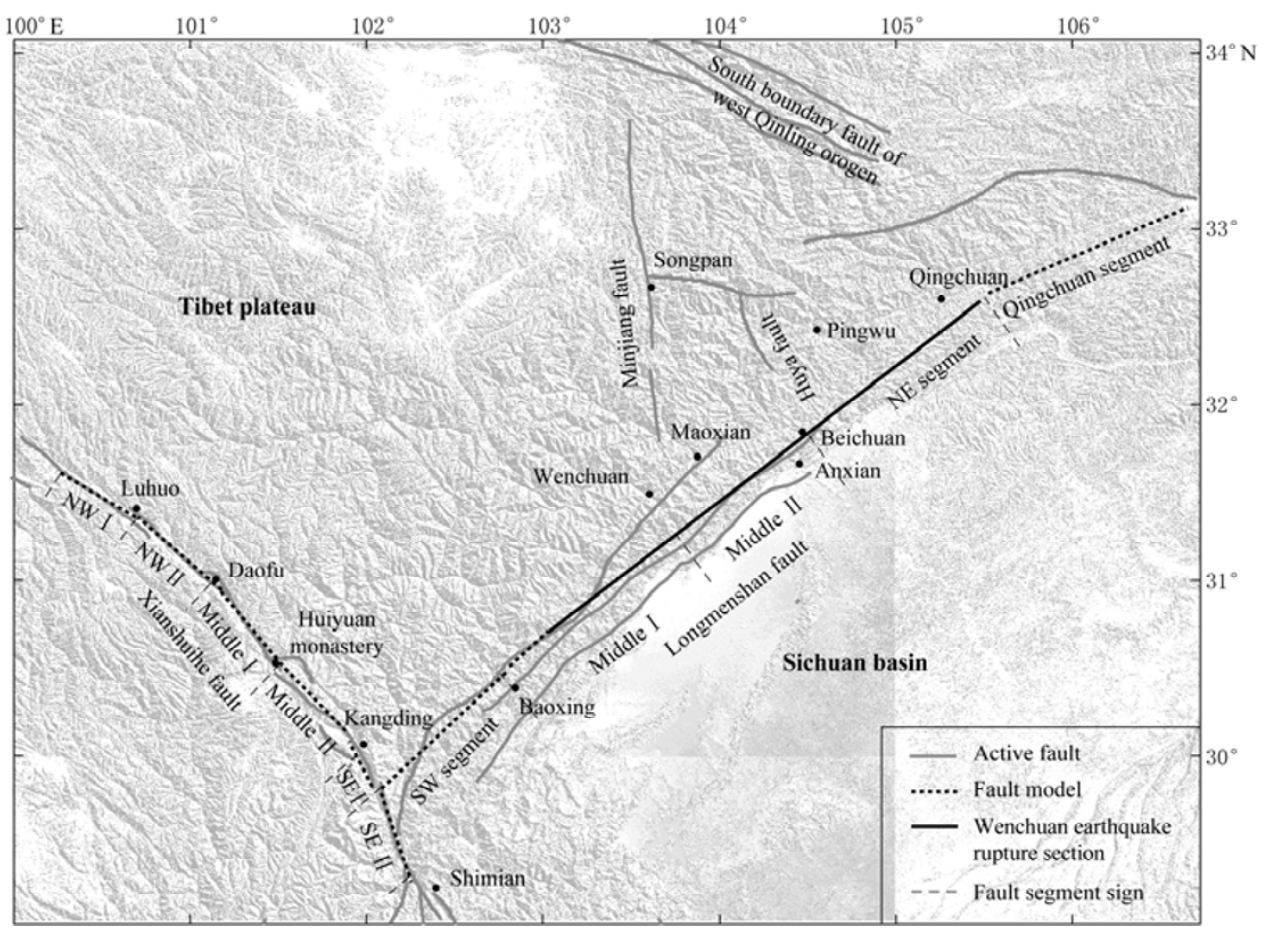

Figure 3 Fault segmentation model of Longmenshan fault and Xianshuihe fault.

3-D half-space dislocation is not very sensitive to the locking depth (Cheng, 2008).

The present-day velocities of the faults in this region were inverted using GPS and leveling data (Cheng, 2008). The inversion used two parts of GPS data. One, with the observations in 1999, 2001, 2004 and 2007 and the occupation of at least four days each, is from crustal Movement Observation Network of China (CMONOC) (Gan et al, 2007); the other, with yearly observation at least 60 hours each during 2005-2007, is from the National Basic Key Project (Shen et al, 2005; Wang et al, 2008d). The leveling data during 1993-2006 are collected from Wang et al (2008b). After several times of inversion based on GPS data and leveling data using the faults geometric model, the optimal results were reached with little difference from the geological results (Xu et al, 2003). They are also similar to the results of rigid block motion model (Shen et al, 2005) and linked-faultelement model (Wang et al, 2008d). But our model took the dip angles of all the faults into consideration, which will make our results more practical.

\section{Coseismic deformation field of Wen- chuan earthquake}

After the Wenchuan earthquake, lots of studies have concentrated on the coseismic rupture point (Wang et al, 2008c; Ji and Hayes, 2008). Ji and Hayes (2008) inverted the coseismic rupture data using finite element method, and gave the coseismic rupture displacement of the $21 \times 8$ fault elements. In their results, the rupture length is $300 \mathrm{~km}$, depth is about $20 \mathrm{~km}$, the maximal offset is more than $9 \mathrm{~km}$, and the strike, dip angle of rupture plane are $229^{\circ}$ and $33^{\circ}$, respectively.

We input the coseismic rupture data above into the 3-D fault geometric model of ours (Figure 2), which is also the model we used to invert the faults' long-term slip rate using GPS and leveling data. And we refined the rupture section into the $21 \times 8$ fault elements in accord with the coseismic rupture data. Based on the coseismic rupture data and Okada's coseismic dislocation model, in which the medium parameter $\lambda$ is equal to $\mu$, we calculated the coseismic deformation field of the Wenchuan $M_{\mathrm{S}} 8.0$ earthquake with large area in Sichuan-Yunnan region (Figure 4). The coseismic deformation reflects the adjustment of crustal deformation in large area, especially around the Longmenshan fault with the clearest deformation. This result is similar to the coseismic deformation field given by GPS observation only in smaller area (Working Group of State Key Scientific Project and Crustal Movement Observation Network of China, 2008). 
Table 1 Geometric segmentation model, fault segment slip rate by inversion and fault parameters (Cheng, 2008)

\begin{tabular}{|c|c|c|c|c|c|c|c|c|}
\hline \multirow{2}{*}{\multicolumn{3}{|c|}{ Active faults and segments }} & \multicolumn{2}{|c|}{$\begin{array}{l}\text { Fault velocities inversion from } \\
\text { GPS and Leveling data }\end{array}$} & \multicolumn{4}{|c|}{ Fault parameters and their reference } \\
\hline & & & $\begin{array}{l}\text { Strike-slip } \\
/ \mathrm{mm} \cdot \mathrm{a}^{-1}\end{array}$ & $\begin{array}{l}\text { Dip-slip } \\
/ \mathrm{mm} \cdot \mathrm{a}^{-1}\end{array}$ & $\begin{array}{l}\text { Dip } \\
\text { angle/ }\end{array}$ & $\begin{array}{l}\text { Dip } \\
\text { direction }\end{array}$ & $\begin{array}{l}\text { Locking } \\
\text { depth } / \mathrm{km}\end{array}$ & Reference \\
\hline \multirow{13}{*}{$\begin{array}{l}\text { East boundary } \\
\text { faults of } \\
\text { Sichuan-Yunnan } \\
\text { rhombic block }\end{array}$} & \multicolumn{2}{|l|}{ Garze-Yushu fault } & $-12.0 \pm 1.3$ & $-0.7 \pm 0.7$ & 70 & $\mathrm{NE}$ & 25 & Zhou et al, 1996 \\
\hline & \multirow{3}{*}{ Xianshuihe fault } & NW segment & $-12.9 \pm 1.4$ & $0 \pm 0.9$ & 70 & $\mathrm{NE}$ & 25 & \multirow{3}{*}{$\begin{array}{l}\text { Li et al, 1986; } \\
\text { Xu et al, } 2003\end{array}$} \\
\hline & & Middle segment & $-11.4 \pm 1.1$ & $0.7 \pm 0.7$ & 70 & $\mathrm{NE}$ & 25 & \\
\hline & & SE segment & $-9.8 \pm 1.4$ & $1.2 \pm 1.0$ & 70 & $\mathrm{NE}$ & 25 & \\
\hline & \multirow{2}{*}{\multicolumn{2}{|c|}{$\begin{array}{l}\text { Anninghe fault } \\
\text { Zemuhe fault }\end{array}$}} & $-6.7 \pm 0.9$ & $0.8 \pm 0.7$ & 70 & $\mathrm{NE}$ & 25 & \multirow{2}{*}{ Xu et al, 2003} \\
\hline & & & $-6.7 \pm 0.9$ & $-2.2 \pm 0.7$ & 60 & $\mathrm{NE}$ & 30 & \\
\hline & \multirow{2}{*}{ Daliangshan fault } & North segment & $-4.2 \pm 1.0$ & $0.7 \pm 0.7$ & 55 & SW & 30 & \multirow{2}{*}{$\begin{array}{l}\text { Xu et al, 2003; } \\
\text { He et al, } 2008\end{array}$} \\
\hline & & South segment & $-3.8 \pm 0.9$ & $1.4 \pm 0.9$ & 70 & SW & 20 & \\
\hline & \multicolumn{2}{|l|}{ Mabian fault } & $-2.6 \pm 0.8$ & $0.7 \pm 0.7$ & 70 & SW & 20 & Zhang et al, 2005 \\
\hline & \multirow{2}{*}{ Huayingshan fault } & West segment & $0.6 \pm 0.7$ & $-0.1 \pm 0.9$ & 70 & SE & 20 & \multirow{2}{*}{ Tang and Han, 1993} \\
\hline & & East segment & $0.4 \pm 0.4$ & $-0.2 \pm 0.5$ & 70 & SE & 20 & \\
\hline & \multirow{2}{*}{ Xiaojiang fault } & North segment & $-10.9 \pm 1.3$ & $-0.9 \pm 0.6$ & 65 & $\mathrm{NE}$ & 25 & \multirow{2}{*}{ Song et al, 1998} \\
\hline & & South segment & $-10.4 \pm 1.3$ & $-0.4 \pm 0.7$ & 65 & $\mathrm{NE}$ & 25 & \\
\hline \multirow{8}{*}{$\begin{array}{l}\text { Active faults } \\
\text { in southeast } \\
\text { margin of } \\
\text { Bayan Har } \\
\text { block }\end{array}$} & \multirow{2}{*}{ Longriba fault } & NE segment & $6.0 \pm 0.9$ & $0.4 \pm 0.4$ & 60 & NW & 15 & \multirow{2}{*}{ Xu et al, 2008} \\
\hline & & SW segment & $6.3 \pm 1.1$ & $-0.5 \pm 0.7$ & 60 & NW & 15 & \\
\hline & \multirow{2}{*}{$\begin{array}{l}\text { Eastern Kunlun } \\
\text { fault }\end{array}$} & SE segment & $-3.2 \pm 1.3$ & $0.4 \pm 0.8$ & 70 & SW & 25 & \multirow{2}{*}{ Kirby et al, 2007} \\
\hline & & NW segment & $-5.4 \pm 1.4$ & $-0.3 \pm 0.5$ & 70 & SW & 25 & \\
\hline & Minjiang fault & & $-0.5 \pm 0.5$ & $0.6 \pm 0.4$ & 65 & NW & 25 & Zhou et al, 2000 \\
\hline & & NE segment & $0 \pm 0.5$ & $-1.3 \pm 0.9$ & 60 & NW & 20 & \\
\hline & Longmenshan & Middle segment & $1.7 \pm 0.8$ & $0.9 \pm 0.7$ & 60 & NW & 20 & Ma et al, 2005 \\
\hline & & SW segment & $2.4 \pm 1.1$ & $1.0 \pm 0.7$ & 60 & NW & 20 & \\
\hline & Thonodian fault & West segment & $0.4 \pm 1.0$ & $0 \pm 0.7$ & 70 & $\mathrm{NE}$ & 15 & Shen et al 2001 \\
\hline & Znongdian rauit & East segment & $1.5 \pm 0.9$ & $-0.3 \pm 0.7$ & 70 & $\mathrm{NE}$ & 15 & Shen el al, 2001 \\
\hline & Jinchoiion foult & North segment & $1.8 \pm 1.4$ & $-1.2 \pm 0.9$ & 70 & NW & 15 & 7 bout 2005 \\
\hline & Jimsinajtáng raút & Middle segment & $2.5 \pm 0.8$ & $1.6 \pm 0.7$ & 70 & NW & 15 & Znou et al, 2003 \\
\hline West boundary & Batang fault & & $4.1 \pm 1.4$ & $-0.4 \pm 0.9$ & 70 & NW & 15 & Zhou et al, 2005 \\
\hline $\begin{array}{l}\text { faults of } \\
\text { Sichuan-Yunnan }\end{array}$ & Lancangjiang fault & & $-0.2 \pm 0.7$ & $0.8 \pm 1.9$ & 90 & & 15 & Wang et al, 2001 \\
\hline rhombic block & Chenghai fault & & $0.7 \pm 0.7$ & $0 \pm 0.8$ & 70 & W & 15 & IECEA, 1990 \\
\hline & Weixi-Qiaohou faul & & $-0.5 \pm 0.9$ & $0.1 \pm 0.5$ & 75 & E & 15 & Wang, 1990 \\
\hline & & North segment & $2.7 \pm 0.9$ & $-0.3 \pm 0.7$ & 75 & $\mathrm{NE}$ & 15 & Guo et al, 1996 \\
\hline & Honghe fault & Middle segment & $2.9 \pm 0.9$ & $-1.3 \pm 0.7$ & 75 & NE & 15 & Xiang et al 2004 \\
\hline & & South segment & $2.2 \pm 1.3$ & $-0.3 \pm 0.5$ & 75 & NE & 15 & Xiang et al, 2004 \\
\hline & Liton foult & North segment & $-4.1 \pm 1.0$ & $1.9 \pm 0.8$ & 70 & $\mathrm{NE}$ & 15 & $\mathrm{X}_{\mathrm{H}} \mathrm{t}$ ol 2005 \\
\hline Inner faults of & Litang lauit & South segment & $-4.0 \pm 1.3$ & $0.4 \pm 0.5$ & 70 & $\mathrm{NE}$ & 15 & Au et al, 2005 \\
\hline Sichuan-Yunnan & & NE segment & $-1.2 \pm 0.6$ & $0.7 \pm 0.7$ & 70 & NW & 15 & \\
\hline rhombic block & $\begin{array}{l}\text { Lijiang-Xiaojinhe } \\
\text { fault }\end{array}$ & Middle segment & $-0.8 \pm 0.9$ & $-0.2 \pm 0.7$ & 70 & NW & 15 & Xu et al, 2003 \\
\hline & & SW segment & $-0.5 \pm 0.9$ & $-0.5 \pm 0.8$ & 70 & NW & 15 & \\
\hline & Nujiang fault & & $-0.2 \pm 0.5$ & $-0.6 \pm 2.3$ & 75 & $\mathrm{~W}$ & 15 & Li, 1998 \\
\hline Active faults & Nantinghe fault & & $-2.0 \pm 0.9$ & $-0.4 \pm 0.8$ & 80 & NW & 15 & IECEA, 1990 \\
\hline $\begin{array}{l}\text { west to } \\
\text { Sichuan-Yunnan }\end{array}$ & Longling-Lancang & West segment & $0.7 \pm 0.9$ & $1.0 \pm 0.9$ & 75 & SW & 15 & Guo et al. 1999 \\
\hline rhombic block & fault & East segment & $2.0 \pm 1.6$ & $0.9 \pm 0.9$ & 75 & SW & 15 & Guo et al, 1999 \\
\hline & Jinghong fault & & $-4.7 \pm 1.5$ & $0.7 \pm 0.7$ & 70 & SE & 15 & Lacassin et al, 1998 \\
\hline Active faults & Riyueshan fault & & $3.1 \pm 0.9$ & $0.8 \pm 0.4$ & 90 & & 20 & Yuan et al, 2003 \\
\hline around south & Lixian-Luojiapu fau & & $-0.9 \pm 0.5$ & $0.3 \pm 0.4$ & 70 & SE & 20 & Han et al, 2001 \\
\hline $\begin{array}{l}\text { west Qinling } \\
\text { orogen }\end{array}$ & $\begin{array}{l}\text { South boundary fau } \\
\text { west Qinling oroger }\end{array}$ & It of & $-1.6 \pm 0.9$ & $1.0 \pm 0.7$ & 75 & SW & 20 & $\begin{array}{l}\text { Zhang Pei-zhen, } \\
\text { personal communication }\end{array}$ \\
\hline
\end{tabular}

Note: Positive slip rate stands for right-lateral and thrust, negative for left-lateral or normal. IECEA denotes Institute of Geology, China Earthquake Administration. 


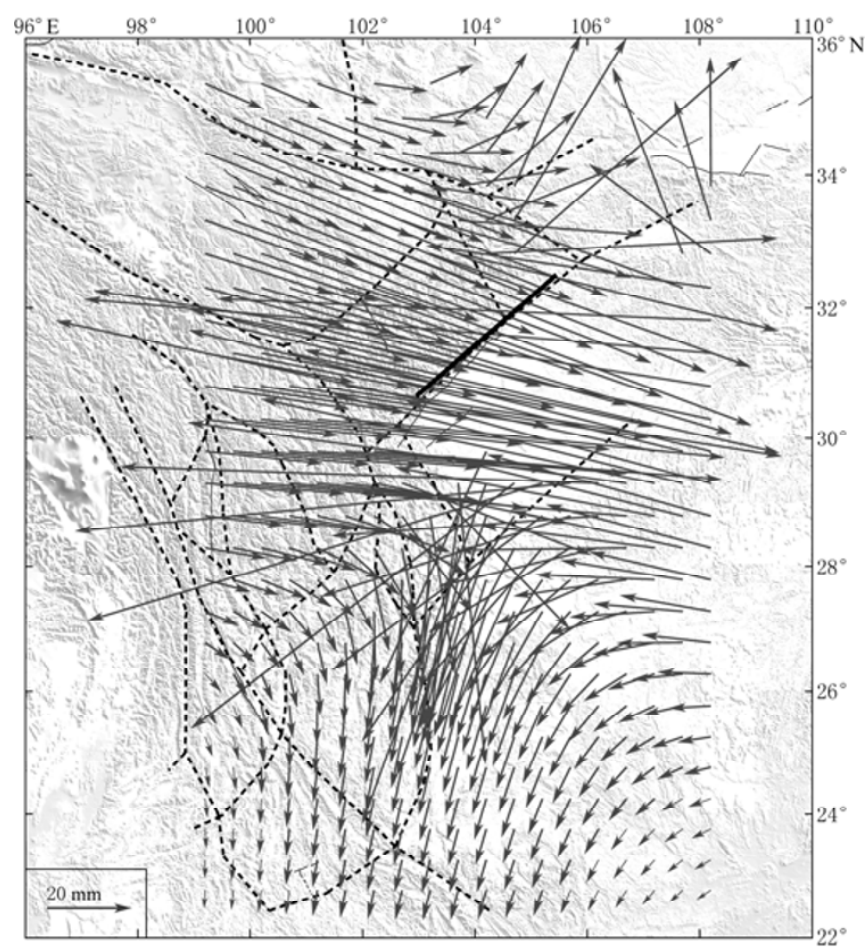

Figure 4 Wenchuan earthquake coseismic deformation field based on coseismic rupture data. Bold line shows the rupture fault segment of the Wenchuan earthquake.

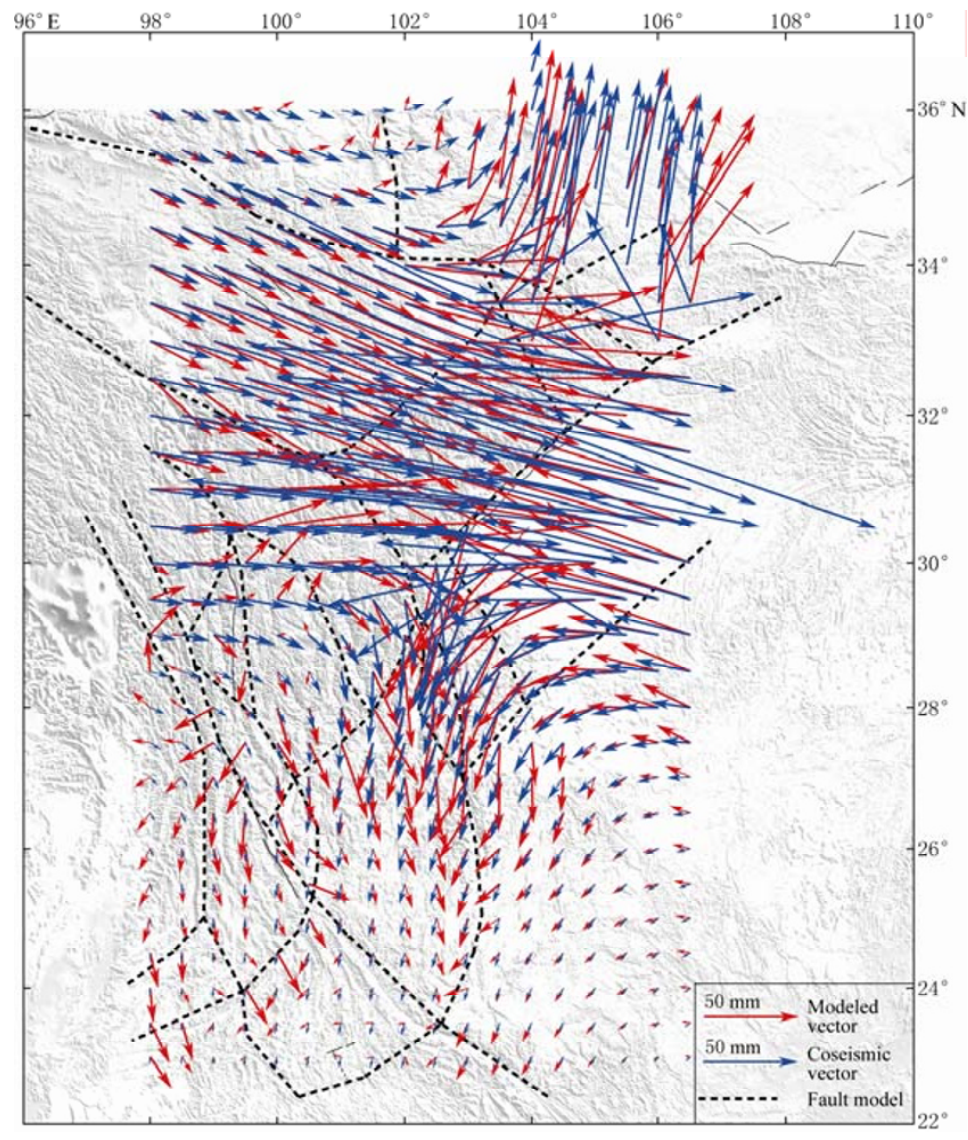

Figure 5 The fitting results of the inversion for the regional active faults' accommodation to coseismic field. 


\section{Potential slip adjustment of other fault segments and its influence on earthquake trends in the coseismic field}

After slip adjustment of regional coseismic deformation field, the faults will change some slip characteristics, which will be reflected as a long-term effect on their activities in interseismic period. Thus we inverted the potential slip adjustment of the other fault segments in interseismic period based on 3-D half-space elastic dislocation model. In this inversion, we added the translation and rotation of the whole regional crustal deformation field, as this adjustment of the regional coseismic deformation will be a long-term effect.
We first inverted the influence of fault segments nearest to the rupture fault, such as Longmenshan fault, Xianshuihe fault, Longriba fault, Minjiang fault, the south boundary fault of west Qinling orogen belt, and eastern Kunlun fault. Then we added the results of the first inversion into the geometric model of the whole regional faults (see Figure 2) as a loose constraint and inverted the slip adjustment of other faults, which made our inversion result more credible. Thus, we could get the best-fitting between the coseismic deformation field and the deformation field caused by slip adjustment of these faults when the square of residual comes out the least. Similarly, we obtained the results of the slip adjustment of all fault segments (Figure 5, Table 2).

Table 2 The influence of Wenchuan earthquake to regional active faults on energy accumulation

\begin{tabular}{|c|c|c|c|c|c|c|c|c|c|}
\hline \multirow{2}{*}{ Fault and segment } & & \multicolumn{2}{|c|}{ Coseismic deformation field } & \multirow{2}{*}{$\begin{array}{c}\text { Influence on } \\
\text { energy } \\
\text { accumulation } \\
\text { /a }\end{array}$} & \multirow{2}{*}{\multicolumn{2}{|c|}{ Fault and segments }} & \multicolumn{2}{|c|}{ Coseismic deformation field } & \multirow{2}{*}{$\begin{array}{c}\text { Influence on } \\
\text { energy } \\
\text { accumulation } \\
\text { /a }\end{array}$} \\
\hline & & \multirow{2}{*}{$\begin{array}{c}\begin{array}{c}\text { Strike-slip } \\
\text { component } \\
/ \mathrm{mm} \cdot \mathrm{a}^{-1}\end{array} \\
90 \pm 110 \\
\end{array}$} & \multirow{2}{*}{$\begin{array}{c}\begin{array}{c}\text { Dip-slip } \\
\text { component } \\
/ \mathrm{mm} \cdot \mathrm{a}^{-1}\end{array} \\
73 \pm 129\end{array}$} & & & & \multirow{3}{*}{$\begin{array}{c}\begin{array}{c}\text { Strike-slip } \\
\text { component } \\
/ \mathrm{mm} \cdot \mathrm{a}^{-1}\end{array} \\
28 \pm 171 \\
30 \pm 160\end{array}$} & \multirow{3}{*}{$\begin{array}{c}\begin{array}{c}\text { Dip-slip } \\
\text { component } \\
/ \mathrm{mm} \cdot \mathrm{a}^{-1}\end{array} \\
-12 \pm 149 \\
-12 \pm 130\end{array}$} & \\
\hline Garze-Yushu faul & & & & -7.1 & Zhongdian fault & West segment & & & 70 \\
\hline \multirow{6}{*}{$\begin{array}{l}\text { Xianshuihe } \\
\text { fault }\end{array}$} & NW I segment & $350 \pm 285$ & $26 \pm 79$ & -27 & & East segment & & & 21 \\
\hline & NW II segment & $348 \pm 285$ & $24 \pm 79$ & -27 & \multirow{2}{*}{ Jinshajiang fault } & North segment & $5 \pm 144$ & $-2 \pm 166$ & 2.4 \\
\hline & Mid I segment & $1415 \pm 223$ & $-195 \pm 174$ & -123 & & Mid segment & $-29 \pm 126$ & $-60 \pm 65$ & -19 \\
\hline & Mid II segment & $1358 \pm 216$ & $-287 \pm 222$ & -117 & & $-37 \pm 134$ & $-12 \pm 149$ & -8.6 \\
\hline & SE I segment & $-203 \pm 312$ & $-210 \pm 161$ & 19 & \multirow{2}{*}{\multicolumn{2}{|c|}{$\begin{array}{l}\text { Northern segment of } \\
\text { Lancangjiang fault }\end{array}$}} & $17 \pm 90$ & $-52 \pm 96$ & 56 \\
\hline & SE II segment & $17 \pm 288$ & $-250 \pm 191$ & 1.4 & & & & & \\
\hline \multirow{2}{*}{\multicolumn{2}{|c|}{$\begin{array}{l}\text { Anninghe fault } \\
\text { Zemuhe fault }\end{array}$}} & $-132 \pm 195$ & $-96 \pm 35$ & 21 & \multirow{2}{*}{\multicolumn{2}{|c|}{$\begin{array}{l}\text { Chenghai fault } \\
\text { Weixi-Qiaohou fault }\end{array}$}} & $15 \pm 81$ & $-35 \pm 75$ & 21 \\
\hline & & $-78 \pm 176$ & $-44 \pm 35$ & 12 & & & $-9 \pm 65$ & $5 \pm 84$ & 19 \\
\hline \multirow{2}{*}{$\begin{array}{l}\text { Daliangshan } \\
\text { fault }\end{array}$} & North segment & $-26 \pm 84$ & $-133 \pm 132$ & 9.1 & \multirow{3}{*}{ Honghe fault } & North segment & $-11 \pm 75$ & $16 \pm 75$ & -3.3 \\
\hline & South segment & $-26 \pm 86$ & $-141 \pm 137$ & 18 & & Mid segment & $-8 \pm 62$ & $23 \pm 78$ & 0.6 \\
\hline \multicolumn{2}{|l|}{ Mabian fault } & $-91 \pm 86$ & $194 \pm 134$ & 51 & & South segment & \multirow{3}{*}{$\begin{array}{l}91 \pm 61 \\
80 \pm 72 \\
\end{array}$} & $30 \pm 62$ & 12 \\
\hline \multirow{2}{*}{$\begin{array}{l}\text { Huayingshan } \\
\text { fault }\end{array}$} & \multirow{2}{*}{$\begin{array}{l}\text { West segment } \\
\text { East segment }\end{array}$} & \multirow{2}{*}{$\begin{array}{c}-7 \pm 79 \\
-20 \pm 63 \\
\end{array}$} & \multirow{2}{*}{$\begin{array}{c}-94 \pm 88 \\
-102 \pm 77 \\
\end{array}$} & \multirow{2}{*}{$\begin{array}{c}24 \\
101\end{array}$} & \multirow[t]{2}{*}{ Litang fault } & \multirow{2}{*}{$\begin{array}{l}\text { North segment } \\
\text { South segment }\end{array}$} & & $-73 \pm 78$ & -11 \\
\hline & & & & & & & & & -17 \\
\hline Xiaojiang & North segment & $23 \pm 89$ & $-78 \pm 83$ & -1.5 & Lijiang- & NE segment & $82 \pm 92$ & $102 \pm 87$ & -14 \\
\hline fault & South segment & $25 \pm 117$ & $-78 \pm 92$ & -2.1 & $\begin{array}{l}\text { Xiaojinne } \\
\text { fault }\end{array}$ & $\begin{array}{l}\text { Mid segment } \\
\text { SW segment }\end{array}$ & $\begin{array}{c}28 \pm 84 \\
-42+96\end{array}$ & $\begin{array}{c}2 \pm 67 \\
-1+81\end{array}$ & $\begin{array}{c}-3.2 \\
43\end{array}$ \\
\hline & $\begin{array}{l}\text { Qingchuan } \\
\text { segment }\end{array}$ & $91 \pm 164$ & $12 \pm 143$ & 9.2 & Nujiang fault & & $12 \pm 92$ & $30 \pm 112$ & 39 \\
\hline Longmenshan & NE segment & $895 \pm 164$ & $55 \pm 143$ & 42 & Nantinghe fault & & $-1 \pm 118$ & $17 \pm 136$ & 2.1 \\
\hline fault & Mid I segment & $3144 \pm 514$ & $188 \pm 193$ & 1490 & Longling- & West segment & $31 \pm 118$ & $-25 \pm 85$ & 31 \\
\hline & Mid II segment & $1894 \pm 371$ & $1031 \pm 148$ & 1121 & Lancang fault & East segment & $32 \pm 127$ & $-38 \pm 85$ & 20 \\
\hline & SW segment & $303 \pm 302$ & $859 \pm 351$ & 235 & Jinghong fault & & $-28 \pm 79$ & $-16 \pm 97$ & 6.3 \\
\hline Longriba fault & NE segment & $-193 \pm 96$ & $-117 \pm 107$ & -30 & Riyueshan fault & & $196 \pm 117$ & $27 \pm 102$ & 61 \\
\hline Longriba rauit & SW segment & $-251 \pm 119$ & $-82 \pm 110$ & -39 & Lixian-Luojiapu & & $-107 \pm 87$ & $-9 \pm 96$ & 110 \\
\hline Eastern Kunlun & SE segment & $-326 \pm 130$ & $116 \pm 124$ & 105 & South boundary & ult of west & $477 \pm 110$ & $-234 \pm 68$ & -149 \\
\hline fault & NW segment & $32 \pm 180$ & $87 \pm 168$ & -5 & Qinling orogen & & & & \\
\hline Minjiang fault & & $569 \pm 151$ & $398 \pm 139$ & -74 & & & & & \\
\hline
\end{tabular}

Table 2 lists the strike-slip and dip-slip component of the slip adjustment in the coseismic deformation field, which shows the field does have influence on slip character of the faults. In order to compare with the long-term slip vector of these faults and to evaluate influence on earthquake occurrence trends of faults, we projected the slip vector of this adjustment to the direction of slip vector inverted from GPS and leveling data 
(Figure 6), and got the influence on earthquake occurrence trends of the faults in the form of yearly strain accumulation increase or decrease.

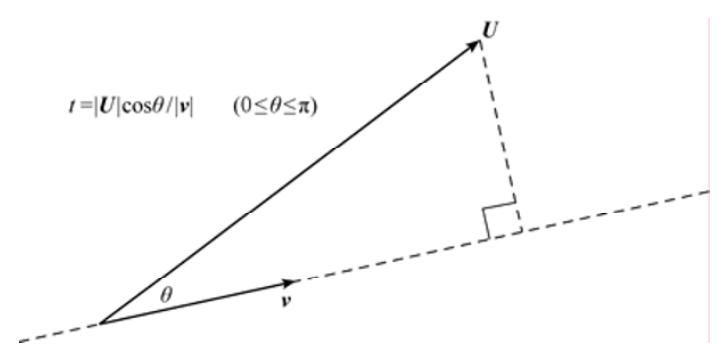

Figure 6 Sketch map showing projection of potential slip distance to secular slip direction. $\boldsymbol{U}$ is fault's slip vector induced by coseismic deformation field (with strike slip and dip slip component); $\boldsymbol{v}$ is fault's slip vector inverted from GPS (with strike slip and dip slip component), and $t$ is the advanced or postponed years of earthquakes occurrence calculated from Wenchuan coseismic deformation field.

This influence can be expressed as that, if the adjustment of the fault has the same slip direction as the slip vector inverted from GPS and leveling data, both left-lateral or both right-lateral, the fault will get an earthquake occurrence trend advanced. In opposition, while the slip fault has the different slip direction from the slip vector inverted from GPS and leveling data, alternatively left-lateral or right-lateral, the fault will get earthquake occurrence trend reduced. Table 2 and Figure 5 give the specific results of our calculation.

\section{Discussion and conclusions}

After the calculation and inversion, we get the influence on earthquake occurrence trends from Wenchuan $M_{\mathrm{S}} 8.0$ earthquake's coseismic field, and the following conclusions are drawn.

The Wenchuan $M_{\mathrm{S}} 8.0$ earthquake has induced a large modification of regional crustal deformation field. The main characters of coseismic deformation field can be seen from Figure 4. Bayan Har block moves to southeast while Sichuan basin moves to northwest. The direction of the coseismic deformation transfers to west around the junction of Xianshuihe and Anninghe fault, and the region to the north of eastern Kunlun fault have a movement northwards.

After the modification of regional crustal deformation field, the regional faults have their earthquake occurrence trends changed as follows (Figure 7).

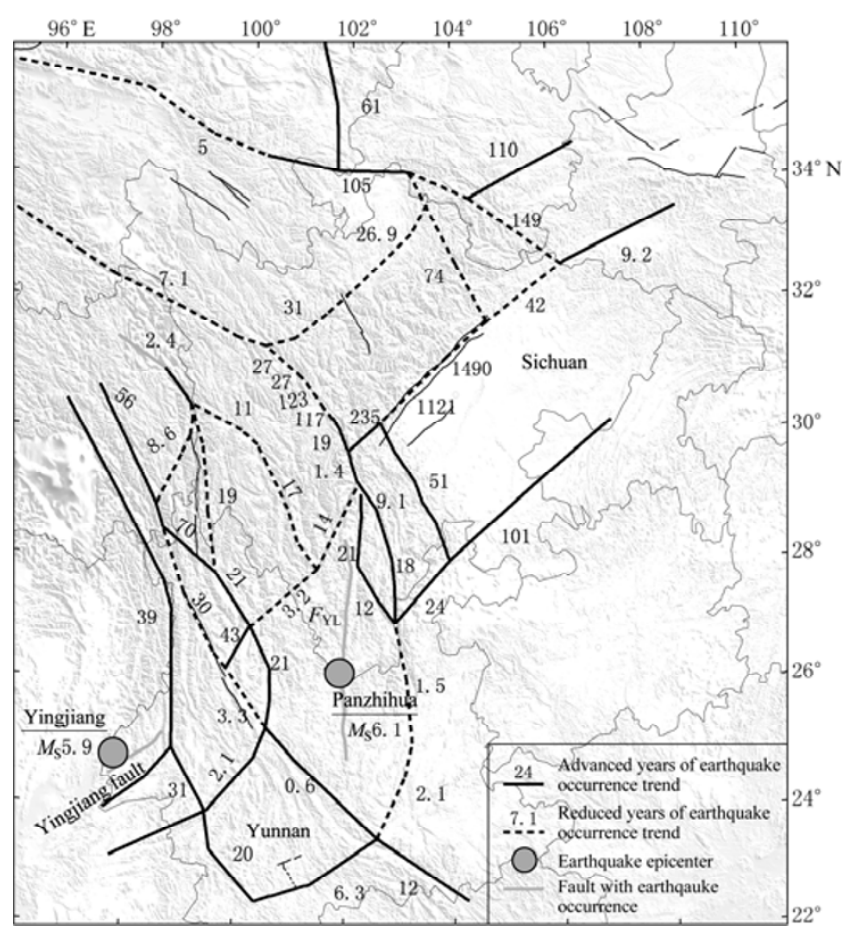

Figure 7 Influence of Wenchuan earthquake on energy accumulation of regional active faults where $F_{\mathrm{YL}}$ represents the Yuanmou-Lüzhijiang fault.

The main rupture fault segments of the Wenchuan $M_{\mathrm{S}} 8.0$ earthquake, which are also the two middle seg- ments of Longmenshan fault, have released their energy accumulation of 1490 and 1121 years respectively. 
Meanwhile the earthquake has caused an increase of energy accumulation on the other segments of Longmenshan fault, especially on the southwest segment, which has got the earthquake occurrence trend advanced of about 235 years.

As regards to Xianshuihe fault, SE I segment and SE II segment (Figure 3), have earthquake occurrence trends advanced 19 years and 1.4 years, respectively. While other segments have theirs reduced. And these results are similar to those on stress trigger studies (Parsons et al, 2008; Toda et al, 2008).

In the northwest region, Minjiang fault and the south boundary fault of west Qinling orogen belt behave right-lateral slip in the coseismic deformation. These slip behaviors, with the opposite direction of the left-lateral slip vector presently, have earthquake occurrence reduced. Longriba fault, which is parallel to Longmenshan fault and has a right-lateral slip vector, also has a right-lateral slip vector in the coseismic field, so the fault have earthquake occurrence advanced.

Because of lacking GPS stations around and large inversion uncertainty of slip vector, the slip vector of the northwest segment of eastern Kunlun fault have large errors, which leads to the projection of slip vector uncertain. The southeast segment of eastern Kunlun fault has earthquake occurrence trend advanced of 105 years in the coseismic field. Riyueshan fault and Lixian-Luojiapu fault, standing north to the eastern Kunlun fault, also have earthquake occurrence trends advanced by the coseismic deformation field.

In the middle region, Anninghe fault, Zemuhe fault, Daliangshan fault, Mabian fault and Huayingshan fault, which consist of the east boundary of Sichuan-Yunnan rhombic block, have a larger energy accumulation. On 30 August 2008, Panzhihua $M_{\mathrm{S}} 6.1$ earthquake occurred on the south stretch of Anninghe fault, which is named Yuanmou-Lüzhijiang fault. And in our results Anninghe fault has about 21 years earthquake occurrence trend advanced. Xiaojiang fault get energy release and earthquake occurrence trends are reduced by the coseismic deformation field. Jinghong fault, the south stretch of Xiaojiang fault, has earthquake occurrence trends advanced because of both left-lateral slip vector in coseismic deformation field and in the deformation field inferred from GPS and leveling data.

As to the inner faults of Sichuan-Yunnan rhombic block, the south and north segment of Litang fault have energy release relative to 17 years and 11 years accumulation. The northeast and middle segments of Lijiang-
Xiaojinhe fault have energy release while its southwest segment has energy increase.

The faults west to Sichuan-Yunnan rhombic block, also have uncertainty in our results with large errors. The middle segment of Jinshajiang fault get 19 years reduced of earthquake occurrence trend, while the north segment has 2.4 years advanced. Batang fault gets earthquake occurrence trend reduced about 8.6 years, the north segment of Lancangjiang fault has been advanced 56 years. The east and west segment of Zhongdian fault have about 21 and 70 years advanced, and Chenghai fault advanced about 21 years.

The segments of Honghe fault behave differently in the coseismic deformation field. The north segment and north stretch segment named Weixi-Qiaohou fault have energy increased, while the south segment have energy released, and we can not distinguish the energy accumulation of middle segment increased or decreased.

The southwest Sichuan-Yunnan region, where lots of strong earthquakes happened in history, has energy increased on the faults like Nujiang fault, LonglingLancang fault and Nantinghe fault. The Yingjiang $M_{\mathrm{S}} 5.9$ earthquake occurred on Yingjiang fault on 21 August 2008. In our results, the Yingjiang fault can be seen as the south segment of Lancangjiang fault because of the simplification of faults, so it stands in the region with earthquake occurrence trend advanced.

After that, we have got the conclusions that two places have the most dangerous faults of earthquake hazard in Sichuan-Yunnan region: the middle section of eastern boundary of Sichuan-Yunnan rhombic block and the western part of Sichuan-Yunnan region. The former includes Anninghe fault, Daliangshan fault, Mabian fault, the southwest segment of Longmenshan fault and the southeast segment of Xianshuihe fault; the latter includes Honghe fault, Chenghai fault, the southwest segment of Lijiang-Xiaojinhe fault, Nantinghe fault, Longling-lancang fault and Nujiang fault.

In this paper, we first calculated the coseismic deformation field, and then inverted the faults' potential dislocation displacements using the coseismic deformation field data, and projected these displacements to the slip vectors inverted from GPS and leveling data.

In this procession, the calculation errors are accumulated gradually, also errors exist in the inversion of long-term slip vector. In order to decrease the errors, we used the same 3-D half-space fault geometric model, furthermore we had the linked fault segments with loose constraint, which can make our results more practical in 
the inversion. Also we inverted several times from near fault area to areas far away gradually, which could get our results more applicable. But it is necessary to point out that there are large uncertainty in particular two kinds of faults: one is the faults with little activity in the inversion results of GPS, like Huayingshan fault; the other is the faults just located in the place where fault's adjustment changes from left-lateral to right-lateral or thrust to extension, like the southwest segment of Xianshuihe fault.

Considering the above reasons, the results are more reliable in the regions like Longmenshan fault, Minjiang fault, Xianshuihe fault, Anninghe fault, Longriba fault, eastern Kunlun fault, the south boundary fault of west Qinling orogen belt, Riyueshan fault, Mabian fault, etc. The results are not clear in the region far away from Wenchuan earthquake, like Xiaojiang fault, Jinshajiang fault, Zhongdian fault, Jinghong fault, Nujiang fault, Longling-Lancangjiang fault, and Nantinghe fault.

In summary, although there are some errors in our calculation and inversions, we still get reliable results on the trends of earthquake occurrence in the place near the epicenter of the Wenchuan $M_{\mathrm{S}} 8.0$ earthquake. The influence on earthquake occurrence trends has been proved to be reliable by Panzhihua $M_{\mathrm{S}} 6.1$ earthquake and Yingjiang $M_{\mathrm{S}} 5.9$ earthquake in 2008 and will show applicability in this region in future.

Acknowledgments This paper is supported by the Key Project of Chinese Programs for Fundamental Research and Development (2004CB418406). The authors are grateful to Chen Ji and Hayes for their coseismic rupture data. Thanks are also given to Professor Peizhen Zhang for his powerpoint file of Sichuan-Yunnan region's tectonic environment. We are particularly indebted to four anonymous reviewers and another reviewer of this English edition for their thorough reviews and thoughtful comments.

\section{References}

Burchfiel B C, Royden L H, van der Hilst R D, Hager B H, Chen Z, King R W, Li C, Lü J, Yao H and Kirby E (2008). A geological and geophysical context for the Wenchuan earthquake of 12 May 2008, Sichuan, People's Republic of China. GSA Today 18(7): 1-11.

Cheng J (2008). Present-day Crustal Deformation of Western Sichuan Inferred From Geodetic Observations. Master Thesis. Institute of Geology, China Earthquake Administration, Beijing, 57-87 (in Chinese with English abstract).

Clark M K, Bush J M and Royden L M (2005). Dynamic topography produced by lower crustal flow against rheological strength heterogeneities bordering the Tibetan Plateau. Geophys J Int 162: 575-590.

Deng Q D (2007). Active Tectonics Map in China. Seismological Press, Beijing, 1 (in Chinese).
Gan W, Svarc J L, Savage J C and Prescott W H (2000). Strain accumulation across the Eastern California Shear Zone at latitude $36^{\circ} 30^{\prime}$ N. J Geophys Res 105: 16 229-16 236.

Gan W, Zhang P, Shen Z, Niu Z, Wang M, Wan Y, Zhou D and Cheng J (2007). Present-day crustal motion within the Tibetan plateau inferred from GPS measurements. J Geophys Res 112: B08416, doi:10.1029/2005JB004120.

Guo S M, Xiang H F, Ji F J and Zhang W X (1996). A study on the relation between quaternary right-lateral slip and tip extension along the Honghe fault. Seismology and Geology 18(4): 301-303 (in Chinese with English abstract).

Guo S M, Xiang H F, Zhou R Q, Xu X W, Dong X Q and Zhang W X (1999). Longling-Lancang fault zone in southwest Yunnan, China. Chinese Sci Bull 45(5): 376-379.

Han Z J, Xiang H F and Ran Y K (2001). Activity analysis of Lixian-Luojiapu fault zone in the east boundary of Tibetan plateau since the late-Pleistocene. Seismology and Geology 23(1): 43-48 (in Chinese with English abstract).

He H L, Ikeda Y, He Y L, Togo M, Chen J, Chen C Y, Tajikara M, Echigo T and Okada S (2008). Newly-generated Daliangshan fault zone - Shortcutting on the central section of Xianshuihe-Xiaojiang fault system. Science in China (Series D) 51(9): $1248-1258$.

Institute of Geology, State Seismological Bureau (1990). Active Faults in Northwest Yunnan Region. Seismological Press, Beijing, 106-116 (in Chinese).

Ji C and Hayes G (2008). Preliminary result of the May 12, $2008 M_{\mathrm{W}} 7.9$ eastern Sichuan, China earthquake. 2008-10-30. http://earthquake.usgs.gov/ eqcenter/eqinthenews/2008/us2008ryan/finite_fault.php.

Kirby E, Harkins N, Wang E, Shi X H, Fan C and Burbank D (2007). Slip rate gradients along the eastern Kunlun fault. Tectonics 26: TC2010, 1-16.

Lacassin P, Replumaz A and Leloup P H (1998). Hairpin river loops and slip-sense inversion on southeast Asian strike-slip faults. Geology 26: $703-706$.

Li J X (1998). Neotectonic feature of the Nujiang fault zone in Western Yunnan. Seismology and Geology 20: 312-320 (in Chinese with English abstract).

Li T S, You Z L, Du Q F, Wu Z X and Jiang Y P (1986). Geological characteristics and the pattern of movement on the Xianshuihe fault zone. In: Seismological Bureau of Sichuan Province eds. Proceedings of Conference on the Xianshuihe Fault Zone. Seismological Press, Beijing, 1-7 (in Chinese).

Ma B Q, Su G, Hou Z H and Shu S B (2005). Late Quaternary slip rate of the middle segment of Longmenshan fault zone. Seismology and Geology 27(2): 234-242 (in Chinese with English abstract).

Okada Y (1985). Surface deformation due to shear and tensile faults in a half-space. Bull Seism Soc Amer 75: 1 135-1 154.

Okada Y (1992). Internal deformation due to shear and tensile faults in a half-space. Bull Seism Soc Amer 82: 1 018-1 040.

Parsons T (2002). Post-1906 stress recovery of the San Andreas fault system calculated from three-dimensional finite element analysis. J Geophys Res 107(B8): 2162, 10.1029/2001JB001051.

Parsons T, Ji C and Kirby E (2008). Stress changes from the 2008 Wenchuan earthquake and increased hazard in the Sichuan basin. Nature 454: 509-510.

Prescott W H and Yu S B (1986). Geodetic measurement of horizontal deformation in the northern San Francisco Bay region, California. $J$ Geophys Res 91: 7 475-7 484.

Savage J C, Svarc J L and Prescott W H (1999). Geodetic estimates of fault slip rates in the San Francisco Bay area. J Geophys Res 104: 4 995-5 002.

Shen J, Wang Y P and Ren J W (2001). The Quaternary right-lateral strike-slipping on the Deqin-Zhongdian-Daju fault zone in Yunnan, China. In: Ma Z J ed. Study on Recent Deformation and Dynamics of the Lithosphere of Qinghai-Xizang Plateau. Seismological Press, Beijing, 123-136 (in Chinese).

Shen Z-K, Lü J, Wang M and Bürgmann R (2005). Contemporary crustal deformation around the southeast borderland of the Tibetan Plateau. $J$ Geophys Res 110: B11409, doi:10.1029/2004JB003421.

Song F M, Wang Y P and Yu W X (1998). The Xiaojiang Active Fault. Seismological Press, Beijing, 149-151 (in Chinese).

Tang R C and Han W B (1993). Active Faults and Earthquakes in Sichuan 
Province, China. Seismological Press, Beijing, 149-152 (in Chinese).

Toda S, Lin J, Meghraoui M and Stain R S (2008). 12 May 2008 M=7.9 Wenchuan, China, earthquake calculated to increase failure stress and seismicity rate on three major fault systems. Geophys Res Lett 35: L17305, doi:10.1029/2008GL34903.

Wan Y G, Shen Z K, Sheng S Z and Xu X F (2009). The influence of 2008 Wenchuan earthquake on surrounding faults. Acta Seismologica Sinica 31(2): 128-139 (in Chinese with English abstract).

Wan Y G, Shen Z K, Zeng Y H and Sheng S Z (2007). Evolution of cumulative coulomb failure stress in northeastern Qinghai-Xizang (Tibetan) Plateau and its effect on large earthquake occurrence. Acta Seismologica Sinica 20(2): 117-132

Wang G Z, Hu R Z, Fang W X and Tao X F (2001). Strike-slip deformation in Lancang river fault zone and relationship with Ge ore deposit in Linchang, Yunnan. Acta Mineralogica Sinica 21(4): 695-698 (in Chinese with English abstract).

Wang H, Liu J, Shi Y L, Zhang H and Zhang G M (2008a). Dynamic simulation of interactions between major earthquakes on the Xianshuihe fault zone. Science in China (Series D) 51(10): $1388-1400$.

Wang J N (1990). The Weixi-Qiaohou fault zone. In: Institute of Geology, China Seismological Bureau eds. Active Faults in Northwest Yunnan Region. Seismological Press, Beijing, 116-120 (in Chinese with English abstract).

Wang Q L, Cui D X, Wang W P, Zhang S X, Liu J W and Shi Q (2008b). Researches on current vertical crust movement in western Sichuan area. Science in China (Series D) 38(5): 598-610 (in Chinese).

Wang W M, Zhao L F, Li J and Yao Z X (2008c). Rupture process of the $M_{\mathrm{S}}$ 8.0 Wenchuan earthquake of Sichuan, China. Chinese J Geophys 51(5): 1403-1 410 .

Wang Y Z, Wang E N, Shen Z K, Wang M, Gan W J, Qiao X J, Meng G J, Li T M, Tao W, Yang Y L, Cheng J and Li P (2008d). GPS-constrained inversion of present-day slip rates along major faults of the Sichuan-Yunnan region, China. Science in China (Series D) 51(9): 1 267-1 283.

Wen X Z, Allen C R, Luo Z L, Qian H, Zhou H W and Huang W S (1989). Segmentation, geometric features, and their seismotectonic implications for the Holocene Xianshuihe fault zone. Acta Seismologica Sinica 11: 362-372 (in Chinese with English abstract).

Working Group of State Key Scientific Project and Crustal Movement Observation Network of China (2008). The coseismic deformation field of Wenchuan $M_{\mathrm{S}} 8.0$ earthquake in 2008 inferred from GPS observation. Science in China (Series D) 38(10): 1 195-1 206 (in Chinese).
Xiang H F, Han Z J, Guo S M, Zhang W X and Chen L C (2004). Large scale dextral strike-slip movement and associated tectonic deformation along the Red-River Fault Zone. Seismology and Geology 26(4): 598-610 (in Chinese with English abstract).

Xu X W, Wen X Z, Chen G H and Yu G H (2008). Discovery of the Longriba fault zone in eastern Bayan Har block, China and its tectonic implication. Science in China (Series D) 51(9): 1 209-1 223.

Xu X W, Wen X Z, Yu G H, Zheng R Z, Luo H Y and Zheng B (2005). Average slip rate, earthquake rupturing segmentation and recurrence behavior on the Litang fault zone, western Sichuan Province, China. Science in China (Series D) 48(8): 1 183-1 196.

Xu X W, Wen X Z, Zheng R Z, Ma W T, Song F M and Yu G H (2003). The newest way and force source of active block in Sichuan-Yunnan area. Science in China (Series D) 33(Suppl. 1): 151-161 (in Chinese).

Yuan D Y, Liu X L, Zhang P Z and Liu B C (2003). A preliminary study on palaeo-earthquake events of the Reshui-Riyueshan Mt. active fault zone in Qinghai province. Seismology and Geology 25(1): 155-165 (in Chinese with English abstract).

Zhang S M, Nie G Z, Liu X D, Ren J J and Su G (2005). Kinematical and structural patterns of Yingjing-Mabian-Yanjin thrust fault zone, southeast of Tibetan plateau, and its segmentation from earthquakes. Seismology and Geology 27(2): 221-233 (in Chinese with English abstract).

Zhou R J, Chen G X, Li Y, Zhou C H, Gong Y, He Y L and Li X G (2005). Research on active faults in Litang-Batang region, western Sichuan Province, and the seismogenic structures of the 1989 Batang M6.7 earthquake swarm. Seismology and Geology 27(1): 31-43 (in Chinese with English abstract).

Zhou R J, Ma S and Cai C X (1996). Late Quaternary active features of the Ganzi-Yushu fault zone. Earthquake Research in China 12(3): 250-260 (in Chinese with English abstract).

Zhou R J, Pu X H, He Y L, Li X G and Ge T Y (2000). Recent activity of Minjiang fault zone, uplift of Minshan block and their relationship with seismicity of Sichuan. Seismology and Geology 22(3): 285-294 (in Chinese with English abstract).

Zhu A L, Xu X W, Zhou Y S, Yin J Y, Gan W J and Chen G H (2005). Relocation of small earthquakes in western Sichuan, China and its implications for active tectonics. Chinese J Geophys 48(3): 629-636 (in Chinese with English abstract). 